Key Words:

Slit Trenches

Activated Carbon Vessels

Porflow

Retention:

Permanent

\title{
SPECIAL ANALYSIS: \\ DISPOSAL OF ETF ACTIVATED CARBON VESSELS IN SLIT TRENCHES AT THE E-AREA LOW-LEVEL WASTE FACILITY
}

Prepared by:

Leonard B. Collard

June 13, 2003

Westinghouse Savannah River Company

Savannah River Site

Aiken, SC 29808

Prepared for the U.S. Department of Energy Under Contract Number DE-AC09-96SR18500

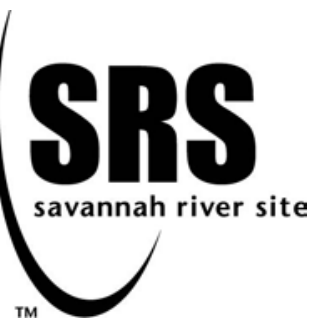


This document was prepared in conjunction with work accomplished under Contract No. DE-AC09-96SR18500 with the U. S. Department of Energy.

\section{DISCLAIMER}

This report was prepared as an account of work sponsored by an agency of the United States Government. Neither the United States Government nor any agency thereof, nor any of their employees, makes any warranty, express or implied, or assumes any legal liability or responsibility for the accuracy, completeness, or usefulness of any information, apparatus, product or process disclosed, or represents that its use would not infringe privately owned rights. Reference herein to any specific commercial product, process or service by trade name, trademark, manufacturer, or otherwise does not necessarily constitute or imply its endorsement, recommendation, or favoring by the United States Government or any agency thereof. The views and opinions of authors expressed herein do not necessarily state or reflect those of the United States Government or any agency thereof.

This report has been reproduced directly from the best available copy.

Available for sale to the public, in paper, from: U.S. Department of Commerce, National Technical Information Service, 5285 Port Royal Road, Springfield, VA 22161, phone: (800) 553-6847, fax: (703) 605-6900

email: orders@ntis.fedworld.gov

online ordering: http://www.ntis.gov/help/index.asp

Available electronically at http://www.osti.gov/bridge

Available for a processing fee to U.S. Department of Energy and its contractors, in paper, from: U.S. Department of Energy, Office of Scientific and Technical Information, P.O. Box 62, Oak Ridge, TN 37831-0062,

phone: (865)576-8401,

fax: (865)576-5728

email: $\underline{\text { reports@ adonis.osti.gov }}$ 
Key Words:

Slit Trenches

Activated Carbon Vessels

Porflow

\section{SPECIAL ANALYSIS: \\ DISPOSAL OF ETF ACTIVATED CARBON VESSELS IN SLIT TRENCHES AT THE E-AREA LOW-LEVEL WASTE FACILITY}

Prepared by:

Leonard B. Collard

June 13, 2003

Westinghouse Savannah River Company

Savannah River Site

Aiken, SC 29808

Prepared for the U.S. Department of Energy Under

Contract Number DE-AC09-96SR18500

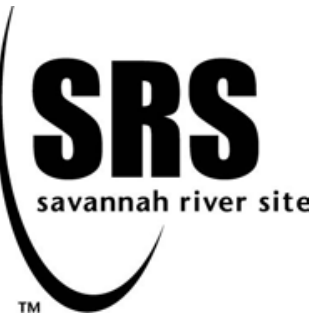


This page intentionally left blank 


\section{TABLE OF CONTENTS}

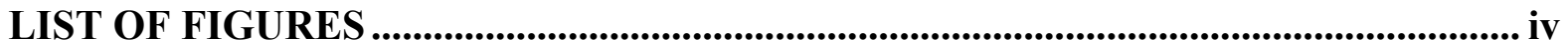

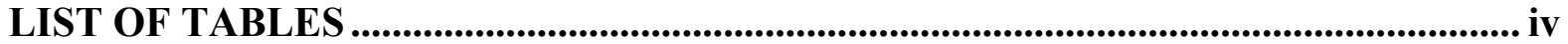

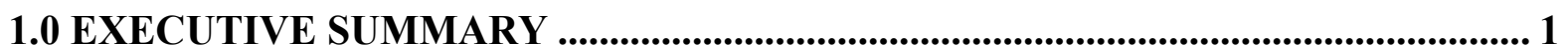

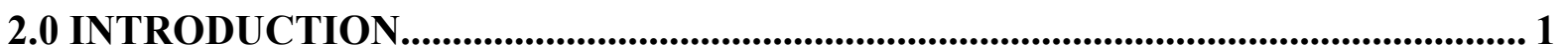

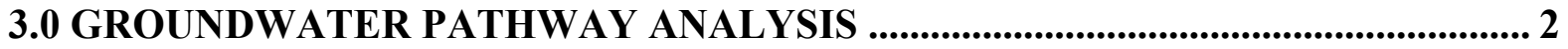

4.0 INTRUDER ANALYSIS ................................................................................. 3

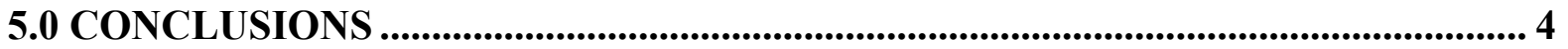

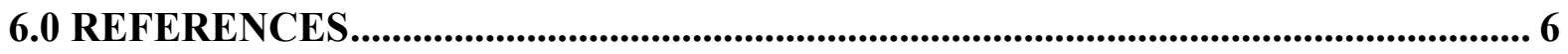

Appendix A. Flux and Concentration Plots.......................................................................... 7

Appendix B. Design Check.................................................................................................................. 9 


\section{LIST OF FIGURES}

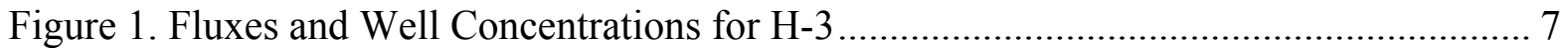

Figure 2. Fluxes and Well Concentrations for $\mathrm{H}-3$ C .................................................... 7

Figure 3. Fluxes and Well Concentrations for $\mathrm{I}-12 \overline{9}$................................................. 8

Figure 4. Fluxes and Well Concentrations for I-129_C................................................... 8

\section{LIST OF TABLES}

Table 1. Peak contaminant flux, well concentration, and inventory limit ........................... 3

Table 2. Residential scenario at 100 years................................................................. 3

Table 3. Post-Drilling scenario at 100 years ............................................................... 3

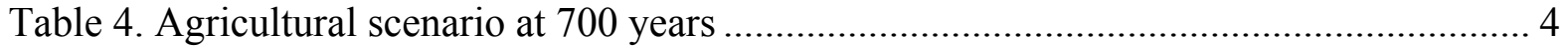

Table 5. Overall inventory limits and limiting pathway ................................................ 4

Table 6. Consumption of inventory limit and facility volume for disposal of ETF carbon

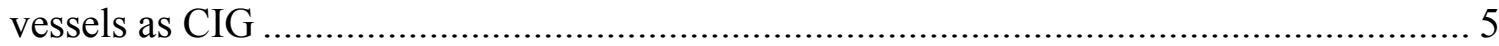

Table 7. Consumption of inventory limit and facility volume for disposal of ETF carbon

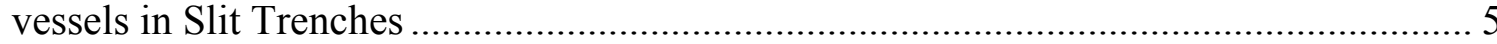




\subsection{EXECUTIVE SUMMARY}

This Special Analysis (SA) addresses two contaminants of concern, H-3 and I-129, in three Effluent Treatment Facility (ETF) Activated Carbon Vessels awaiting disposal as solid waste. The Unreviewed Disposal Question (UDQ) evaluation (Collard, 2002) listed two options for disposal of this waste, disposal as Components-in-Grout (CIG) or disposal in Slit Trenches with sealed openings to restrict release of $\mathrm{H}-3$ from the vessels.

The first option was analyzed in the CIG SA (Collard and Cook, 2003). The second option is analyzed in this SA. Consumption of the CIG inventory limit and consumption of CIG facility volume are shown in Table 6 for the ETF vessels to allow easy comparison with the consumption of Slit Trench inventory limit and consumption of the Slit Trench facility volume shown in Table 7. The inventory projections are based on doubling the inventory of the three ETF vessels in the E-Area to account for the unknown inventory of three ETF vessels in the ETF (Sink 2003).

The facility volume consumption is about $0.6 \%$ for both facilities. $\mathrm{H}-3$ in the vessels (called H-3_C) consumes insignificant amounts of its inventory limits in both facilities. The I-129 in the vessels (called I-129_C) consumes about 139\% of its inventory limit for CIG trenches and about $6 \%$ for Slit Trenches.

The inventory consumption for I-129_C is much higher in the CIG trenches because the grout causes the waste zone to be transformed from an acidic environment to a cementitious environment where the I-129 is not as strongly adsorbed in the waste zone. In CIG trenches rainwater is transformed when it contacts the overlying grout, then the transformed rainwater infiltrates and transforms the waste zone. For an acidic environment Kaplan et al. (1999) measured the adsorption property of I-129 on the ETF activated carbon as a $\mathrm{Kd}$ of $7400 \mathrm{ml} / \mathrm{g}$. For a cementitious environment the $\mathrm{Kd}$ is only $600 \mathrm{ml} / \mathrm{g}$. Thus, while the grout impedes water movement, which tends to reduce well concentrations, it also creates an environment where the sorption is reduced for I-129 on ETF activated carbon that tends to increase well concentrations.

When the grout ultimately is assumed to degrade hydraulically, the water movement is not impeded as much as the release is accelerated by the presence of the grout. Under these conditions for the CIG trenches relative to the Slit Trenches, the well concentrations are higher, the inventory limit is lower and for a given inventory the inventory limit consumption is higher.

\subsection{INTRODUCTION}

This Special Analysis (SA) addresses two contaminants of concern, H-3 and I-129, in three Effluent Treatment Facility (ETF) Activated Carbon Vessels awaiting disposal as solid waste. The Unreviewed Disposal Question (UDQ) evaluation (Collard, 2002) listed two options for disposal of this waste, disposal as Components-in-Grout (CIG) or disposal in Slit Trenches with sealed openings to restrict release of $\mathrm{H}-3$ from the vessels. 
The first option was analyzed in the CIG SA (Collard and Cook, 2003). The second option is analyzed in this SA.

To restrict release of $\mathrm{H}-3$ from the vessels, the openings must be sealed and the vessel must withstand structural loads. After burial and during the operational phase of the Slit Trenches the structural loads are assumed to consist of earth loads. During closure of the Slit Trenches structural loads could include dynamic compaction. The vessels are assumed to be unable to withstand dynamic compaction, thus credit for sealed openings is only considered during the first 25-year operational phase.

To ensure that the vessels themselves will not fail structurally and release H-3, a separate structural analysis (Estochen, 2002) was conducted. That report examined loading cases for upright vessels and vessels placed on their sides. That report recommended that the vessels be disposed in an upright orientation, but stated that disposal in either orientation would not cause the vessels to breach before the end of the assumed operational period of 25 years.

Preventing release of H-3 and I-129 during the operational period is a major change from the conceptual model used by previous models to analyze their release and movement (Collard, 2001 and McDowell-Boyer et al., 2002). In effect, there should be zero release during the operational stage of the Slit Trenches. Generic wastes release substantial quantities of H-3 and I-129 during the operational stage. That release will not happen for sealed vessels, thus those substantial quantities of H-3 and I-129 would still be available for release from sealed vessels when dynamic compaction occurs. A new model for this SA accounts for 25 years of decay with zero release followed by the typical second stage of an intact cap during 100 years of institutional control and by the typical third stage of a failed cap for the remaining 9875 years.

\subsection{GROUNDWATER PATHWAY ANALYSIS}

The I-129 in the vessels is designated as I-129_C because that is the nomenclature that Solid Waste has applied to that specific waste. A waste-specific $\mathrm{Kd}$ of $7400 \mathrm{ml} / \mathrm{g}$ was measured (Kaplan et al., 1999) that is much higher than the Kd of $0.6 \mathrm{ml} / \mathrm{g}$ for generic I-129. The Kd for the I-129_C is for acidic conditions that are expected to exist in the trenches due to the slightly acidic rainwater that will infiltrate the trench. The $\mathrm{H}-3$ in the vessels is referred to as H-3_C in this report for consistency with the nomenclature for the I-129.

Peak values for the fractional contaminant flux at the water table generated by the vadose zone model and peak values for the concentration at the hypothetical 100-m well are shown in Table 1. The inventory limit for the groundwater pathway is also shown in Table 1. The fractional flux plot and the well concentration plots for each radionuclide are provided in Figures 1-4. The results shown assume that the waste is uniformly distributed throughout one set of five Slit Trenches. 
Table 1. Peak contaminant flux, well concentration, and inventory limit

\begin{tabular}{lcrrrr}
\hline Radionuclide & $\begin{array}{l}\text { Peak Fractional Flux } \\
\text { (Ci per Ci inventory) }\end{array}$ & $\begin{array}{l}\text { Time } \\
\text { (years) }\end{array}$ & $\begin{array}{l}\text { Peak Well } \\
\text { Concentration } \\
\text { (pCi/L per Ci } \\
\text { inventory) }\end{array}$ & $\begin{array}{l}\text { Time } \\
\text { (years) }\end{array}$ & $\begin{array}{l}\text { Groundwater } \\
\text { Pathway } \\
\text { Inventory } \\
\text { Limit } \\
\text { (Ci) }\end{array}$ \\
\hline Generic H-3 & $1.56 \mathrm{E}-01$ & 6.91 & $1.59 \mathrm{E}+03$ & 9.00 & $6.3 \mathrm{E}+00$ \\
H-3_C & $1.61 \mathrm{E}-04$ & 130 & $1.41 \mathrm{E}+00$ & 132 & $7.1 \mathrm{E}+03$ \\
Generic I-129 & $7.27 \mathrm{E}-02$ & 22.3 & $4.77 \mathrm{E}+02$ & 29.0 & $1.0 \mathrm{E}-03$ \\
I-129_C & $5.57 \mathrm{E}-05$ & 8180 & $1.15 \mathrm{E}+00$ & 8720 & $4.3 \mathrm{E}-01$ \\
\hline
\end{tabular}

Results for the generic radionuclides in Table 1 were compared to those in the SA (Cook, 2002) that corrected the Performance Assessment (PA, McDowell-Boyer et al., 2002) and with results in the PA. The only differences for the generic radionuclides was that the PA indicated that the time of the peak flux was at 22.4 years rather than at 22.3 years shown in the current report.

\subsection{INTRUDER ANALYSIS}

The intruder analyses for H-3_C and I-129_C are different from the generic radionuclides because sealed openings delay the release of contaminants and cause more contaminant to remain in the waste zone at any point in time. Results for the residential, post-drilling and agricultural scenarios are shown in Tables 2-4 below.

Table 2. Residential scenario at 100 years

\begin{tabular}{lccc}
\hline Radionuclide & $\begin{array}{c}\text { Fraction } \\
\text { Remaining }\end{array}$ & $\begin{array}{c}\text { Concentration Limit } \\
\left(\mu \mathrm{Ci} / \mathrm{m}^{3}\right)\end{array}$ & $\begin{array}{c}\text { Inventory Limit } \\
(\mathrm{Ci})\end{array}$ \\
\hline Generic H-3 & $0.00 \mathrm{E}+00$ & No limit & No limit \\
H-3_C & $2.19 \mathrm{E}-03$ & No limit & No limit \\
Generic I-129 & $7.28 \mathrm{E}-06$ & $8.1 \mathrm{E}+09$ & $2.3 \mathrm{E}+08$ \\
I-129_C & $1.00 \mathrm{E}+00$ & $5.9 \mathrm{E}+04$ & $1.7 \mathrm{E}+03$ \\
\hline
\end{tabular}

Table 3. Post-Drilling scenario at 100 years

\begin{tabular}{lccc}
\hline Radionuclide & $\begin{array}{c}\text { Fraction } \\
\text { Remaining }\end{array}$ & $\begin{array}{c}\text { Concentration Limit } \\
\left(\mu \mathrm{Ci} / \mathrm{m}^{3}\right)\end{array}$ & $\begin{array}{c}\text { Inventory Limit } \\
(\mathrm{Ci})\end{array}$ \\
\hline Generic H-3 & $0.00 \mathrm{E}+00$ & No limit & No limit \\
H-3_C & $2.19 \mathrm{E}-03$ & $5.9 \mathrm{E}+08$ & $3.1 \mathrm{E}+06$ \\
Generic I-129 & $7.28 \mathrm{E}-06$ & $8.5 \mathrm{E}+09$ & $4.4 \mathrm{E}+07$ \\
I-129_C & $1.00 \mathrm{E}+00$ & $6.2 \mathrm{E}+04$ & $3.2 \mathrm{E}+02$ \\
\hline
\end{tabular}


Table 4. Agricultural scenario at 700 years

\begin{tabular}{lccc}
\hline Radionuclide & $\begin{array}{c}\text { Fraction } \\
\text { Remaining }\end{array}$ & $\begin{array}{c}\text { Concentration Limit } \\
\left(\mu \mathrm{Ci} / \mathrm{m}^{3}\right)\end{array}$ & $\begin{array}{c}\text { Inventory Limit } \\
(\mathrm{Ci})\end{array}$ \\
\hline Generic H-3 & $0.00 \mathrm{E}+00$ & No limit & No limit \\
H-3_C & $0.00 \mathrm{E}+00$ & No limit & No limit \\
Generic I-129 & $0.00 \mathrm{E}+00$ & No limit & No limit \\
I-129_C & $9.71 \mathrm{E}-01$ & $2.1 \mathrm{E}+03$ & $5.9 \mathrm{E}+01$ \\
\hline
\end{tabular}

The air and radon pathways can also provide inventory limits. The air pathway has an inventory limit of 3.2E5 Ci for H-3 (Cook, 2002), which also applies to H-3_C. The air pathway has no limits for I-129 or I-129_C. Radon limits are not applicable for H-3 or I-129.

\subsection{CONCLUSIONS}

The most restrictive pathway or scenario controls the inventory limit for each contaminant. The inventory limit and the most restrictive pathway are shown in Table 5.

The inventory limit for I-129_C is based on acidic conditions. To ensure acidic conditions, ETF activated carbon vessels must be disposed separately from cementitious waste, e.g., concrete rubble. The separation distance should be a minimum of 16 feet in all directions.

In order to readily compare the two disposal options for ETF activated carbon vessels that were listed in the UDQ evaluation (Collard, 2002), the consumption of the inventory limits and facility volumes for each disposal option are provided in tables. Results for the first disposal option as CIG are presented in Table 6. Similar results for disposal in Slit Trenches are provided in Table 7. I-129_C consumes the most inventory, about $138 \%$ for CIG trenches and about $6 \%$ for Slit Trenches.

Table 5. Overall inventory limits and limiting pathway

\begin{tabular}{lcl}
\hline Radionuclide & $\begin{array}{c}\text { Inventory Limit } \\
(\mathrm{Ci})\end{array}$ & $\begin{array}{c}\text { Limiting Pathway } \\
\text { Generic H-3 }\end{array}$ \\
$6.3 \mathrm{E}+00$ & $\mathrm{Gw}$ \\
$\mathrm{H}-3$ C & $7.1 \mathrm{E}+03$ & $\mathrm{Gw}$ \\
Generic I-129 & $1.0 \mathrm{E}-03$ & $\mathrm{Gw}$ \\
$\mathrm{I}-129$ C & $4.3 \mathrm{E}-01$ & $\mathrm{Gw}$ \\
\hline
\end{tabular}


Table 6. Consumption of inventory limit and facility volume for disposal of ETF carbon vessels as CIG

\begin{tabular}{lcccc}
\hline Radionuclide & $\begin{array}{c}\text { Inventory } \\
(\mathrm{Ci})\end{array}$ & $\begin{array}{c}\text { Inventory Limit } \\
(\mathrm{Ci})\end{array}$ & $\begin{array}{c}\text { Consumption of } \\
\text { Inventory Limit } \\
(\%)\end{array}$ & $\begin{array}{c}\text { Consumption of } \\
\text { Facility Volume } \\
(\%)\end{array}$ \\
\hline H-3_C & $2.68 \mathrm{E}-1$ & $1.8 \mathrm{E}+06$ & $1.49 \mathrm{E}-05$ & 0.60 \\
$\mathrm{I}-129 \_\mathrm{C}$ & $2.36 \mathrm{E}-2$ & $1.7 \mathrm{E}-02$ & $1.39 \mathrm{E}+02$ & 0.60 \\
\hline
\end{tabular}

Table 7. Consumption of inventory limit and facility volume for disposal of ETF carbon vessels in Slit Trenches

\begin{tabular}{lcccc}
\hline Radionuclide & $\begin{array}{c}\text { Inventory } \\
(\mathrm{Ci})\end{array}$ & $\begin{array}{c}\text { Inventory Limit } \\
(\mathrm{Ci})\end{array}$ & $\begin{array}{c}\text { Consumption of } \\
\text { Inventory Limit } \\
(\%)\end{array}$ & $\begin{array}{c}\text { Consumption of } \\
\text { Facility Volume } \\
(\%)\end{array}$ \\
\hline Generic H-3 & & $6.3 \mathrm{E}+00$ & & 0.60 \\
H-3_C & $2.68 \mathrm{E}-1$ & $\begin{array}{c}7.1 \mathrm{E}+03 \\
1.0 \mathrm{E}-03\end{array}$ & $3.77 \mathrm{E}-03$ & \\
Generic I-129 & & $4.3 \mathrm{E}-01$ & $5.49 \mathrm{E}+00$ & 0.60 \\
I-129_C & $2.36 \mathrm{E}-2$ & & & \\
\hline
\end{tabular}




\subsection{REFERENCES}

Collard, L.B. 2001. Special Analysis for Disposal of High-Concentration I-129 Waste in Slit Trenches at the E-Area Low-Level Waste Facility, WSRC-TR-2001-00021, Revision 0, Westinghouse Savannah River Company, Aiken, South Carolina, 29808, August 15.

Collard, L.B. 2002. Evaluation of Proposed New LLW Disposal Activity: Disposal of ETF Activated Carbon Vessels in Trenches, WSRC-TR-2002-00339, Revision 0, Westinghouse Savannah River Company, Aiken, South Carolina, 29808, September 3.

Collard, L.B. and J.R. Cook 2003. Special Analysis for Disposal of Cement-Stabilized Encapsulated Waste at the E-Area Low-Level Waste Facility, WSRC-RP-99-00596, Revision 1, Westinghouse Savannah River Company, Aiken, South Carolina, 29808, May 21.

Cook, J.R. 2002. Special Analysis: Correction and Update of E-Area Disposal Limits, WSRC-TR-2002-00047, Revision 2, Westinghouse Savannah River Company, Aiken, South Carolina, 29808, May 2.

Estochen, E.G. 2002. ETF Vessel External Pressure Capacity, Calculation M-CLC-A-00189, Westinghouse Savannah River Company, Aiken, South Carolina, 29808, October 15.

Kaplan, D.I., S.M. Serkiz, and N.C. Bell, 1999. I-129 Desorption from SRS Water Treatment Media From the Effluent Treatment Facility and the F-Area Groundwater Treatment Facility. WSRC-TR-99-00270, Rev. 0. Savannah River Laboratory, Westinghouse Savannah River Company, Aiken, SC., August 24.

McDowell-Boyer, L., A.D. Yu, J.R. Cook, D.C. Kocher, E.L. Wilhite, H. Holmes-Burns, and K.E. Young. 2000. Radiological Performance Assessment for the E-Area Low Level Waste Facility, WSRC-RP-94-218, Revision 1, Westinghouse Savannah River Company, Aiken, South Carolina, 29808, January 31.

Sink, D.F., Jr. 2003. Personal Communication, June 17. 
Appendix A. Flux and Concentration Plots

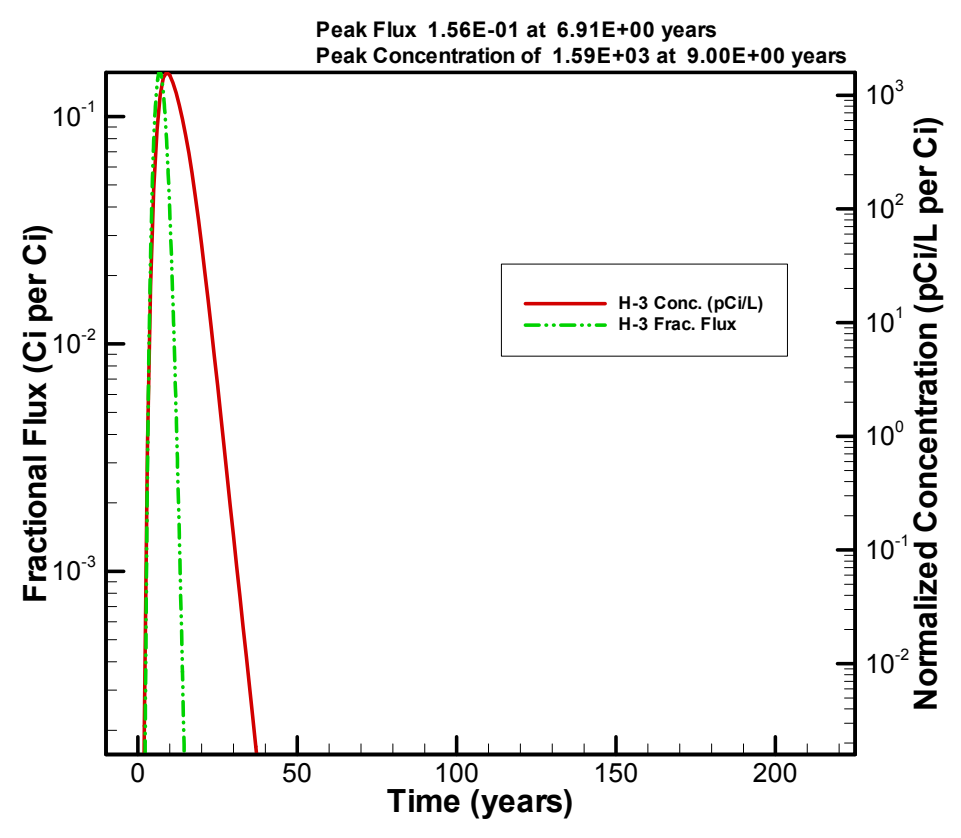

Figure 1. Fluxes and Well Concentrations for $\mathbf{H}-3$

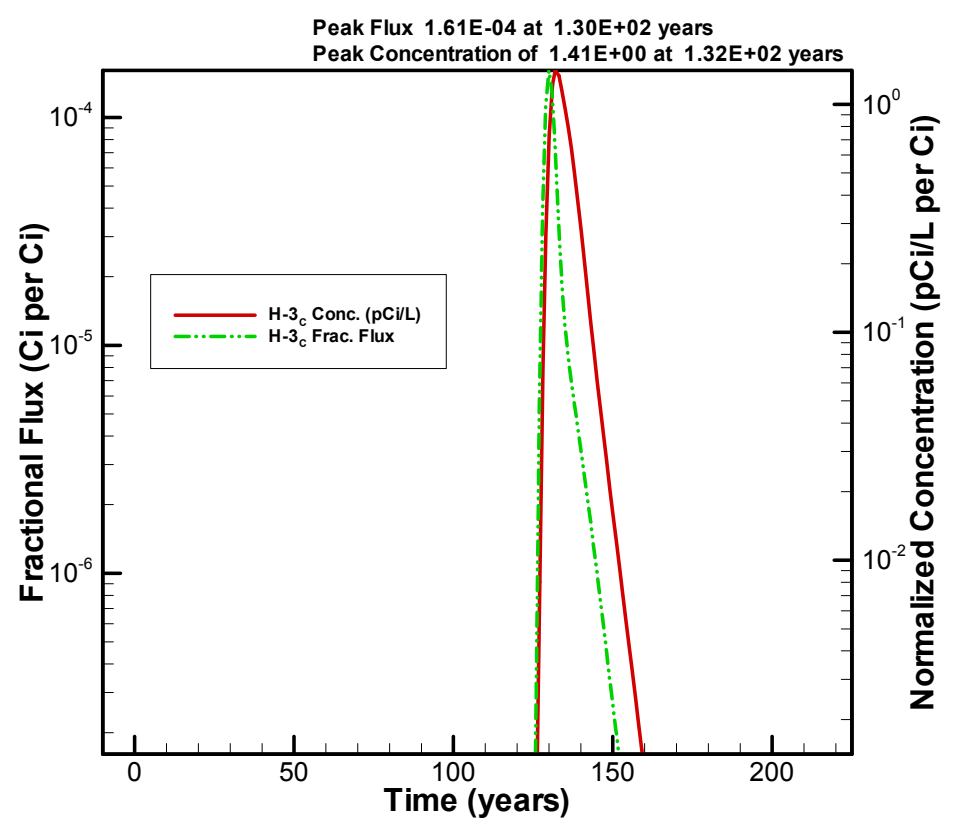

Figure 2. Fluxes and Well Concentrations for H-3_C 


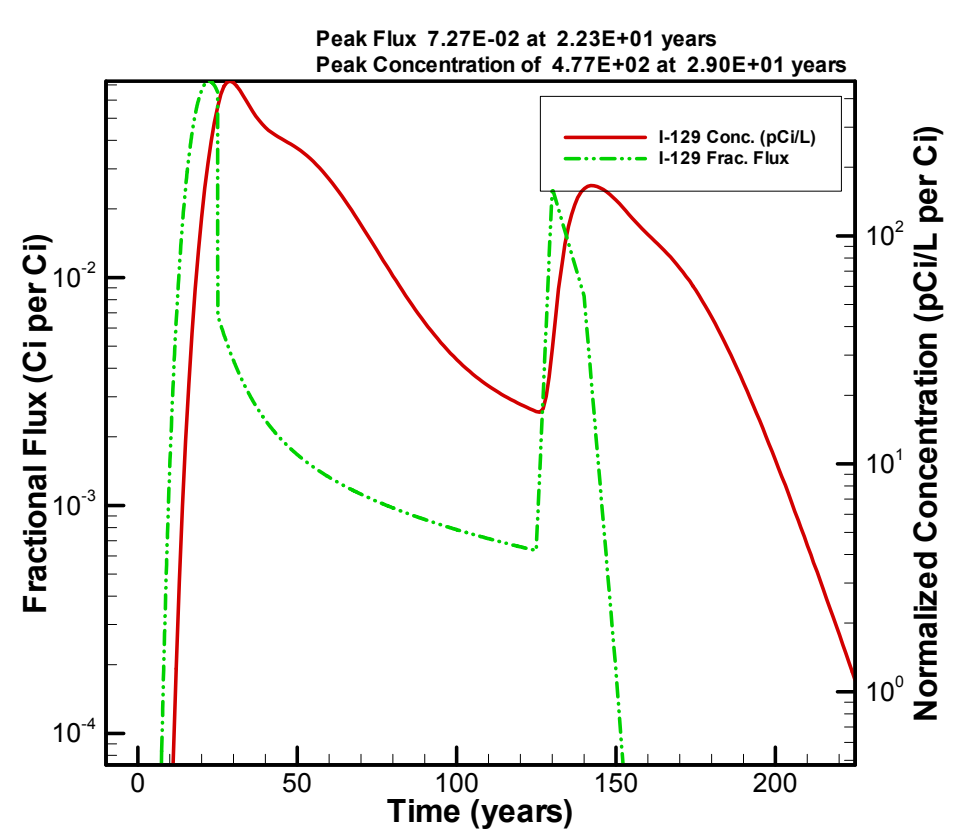

Figure 3. Fluxes and Well Concentrations for I-129

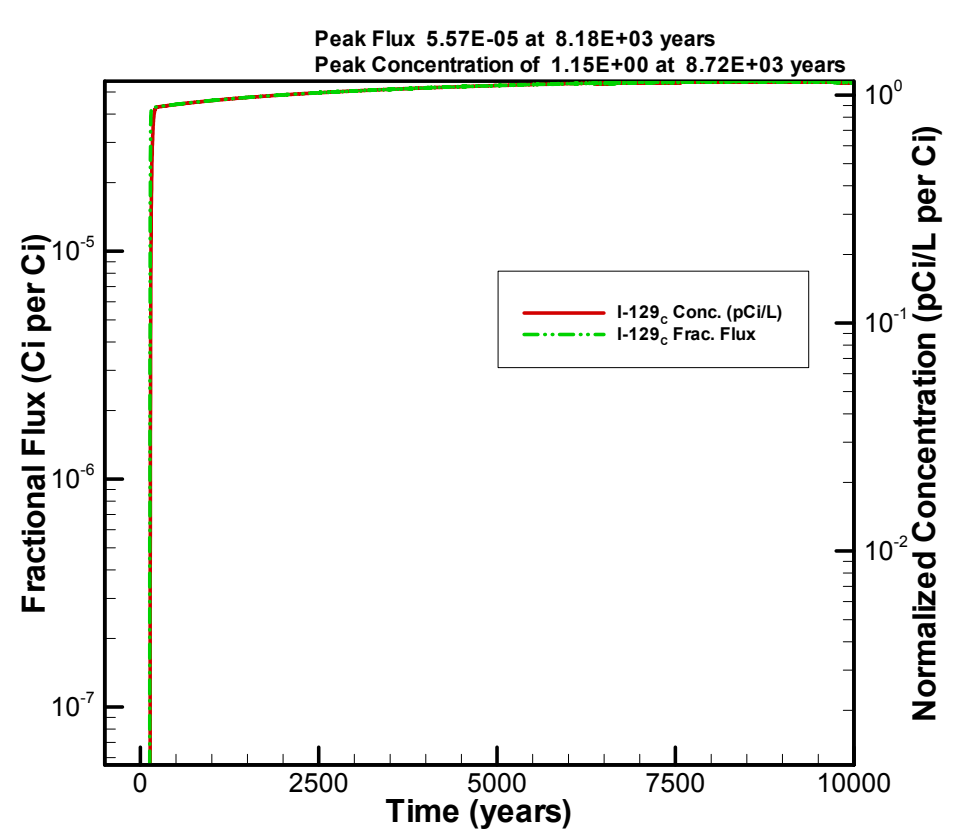

Figure 4. Fluxes and Well Concentrations for I-129_C 


\section{Appendix B. Design Check}

\section{Design check instructions}

\section{DESIGN CHECK INSTRUCTIONS FOR SPECIAL ANALYSIS OF ETF CARBON VESSELS IN SLIT} TRENCHES

Perform a design check for SPECIAL ANALYSIS: DISPOSAL OF THREE ETF ACTIVATED CARBON VESSELS IN SLIT TRENCHES AT THE E-AREA LOW-LEVEL WASTE FACILITY, WSRC-TR-2003-XXXXX, Rev 0, June 13, 2003 following the general guidance provided in WSRC-IM-2002-00011.

Specific instructions for the groundwater pathway analysis are as follow:

1. Check the APPROACH to ensure that the conceptual model for sealed vessels is appropriate

2. Check the MATHEMATICS by

- Checking the intruder spreadsheets

3. Check to ensure that the INPUTS are correct for

- Check that the modeling changes stated in the report were properly implemented, i.e., that the initial inventory was properly decayed until after the Slit Trench operational phase

- The proper Kd for I-129 in the vessels was applied

- The PA models were effectively replicated except for the changes noted above

4. Check to ensure that the OUTPUTS are reasonable by

- For each nuclide, check that the general pattern well concentrations "matches" the general pattern of the fluxes

- Check the plots for generic waste versus PA results

5. TRANSCRIPTION:

- Ensure that the peak concentrations, peak fluxes and times in the figures match the values in the tables. If the numbers are presented at two different locations throughout the report, they should be identical, except for rounding.

- Check the inventory limit table and the tables comparing inventory with limits 


\section{Design check from B.T. Butcher}

\section{DESIGN CHECK INSTRUCTIONS AND REVIEWER COMMENTS FOR SPECIAL ANALYSIS OF ETF CARBON VESSELS IN SLIT TRENCHES}

Perform a design check for SPECIAL ANALYSIS: DISPOSAL OF THREE ETF ACTIVATED CARBON VESSELS IN SLIT TRENCHES AT THE E-AREA LOW-LEVEL WASTE FACILITY, WSRC-TR-2003-00255, Rev 0, June 13, 2003 following the general guidance provided in WSRCIM-2002-00011.

Specific instructions for the groundwater and intruder pathway analysis are provided below. Technical reviewer comments by Tom Butcher are shown in red beneath items checked. Items 3 and 4 were checked by Thong Hang in a separate review.

1. Check the APPROACH to ensure that the conceptual model for sealed vessels is appropriate

The approach taken in this SA was to use the existing PA Slit Trench model and modify it to analyze disposal of ETF Activated Carbon Vessels. The release of contaminants was changed in the model to simulate the vessels being sealed during the first 25 -year operational phase. This delay results in the need to reanalyze both groundwater and intruder pathways. The approach taken to simulate this proposed action is appropriate.

2. Check the MATHEMATICS by

- Checking the intruder spreadsheets

The intruder spreadsheet from the PA Revision 1 was used in the reanalysis of the intruder pathway. Spreadsheet values were cross-checked with values in E-Area PA Revision 1 or the Special Analysis correcting and updating E-Area disposal limits as appropriate. The values and formulas used in this SA are implemented consistently with the PA. The one exception was that the summary section of the spreadsheet where limits from the different pathways are listed side-by-side reference back to the incorrect cell where the limit was first calculated. However, the correct limit value was transcribed to the report. Correct references in cells AL145, AL146, AM145, AM146, AN145 and AN146.

3. Check to ensure that the INPUTS are correct for

- Check that the modeling changes stated in the report were properly implemented, i.e., that the initial inventory was properly decayed until after the Slit Trench operational phase

- The proper Kd for I-129 in the vessels was applied

- The PA models were effectively replicated except for the changes noted above

4. Check to ensure that the OUTPUTS are reasonable by 
- For each nuclide, check that the general pattern well concentrations "matches" the general pattern of the fluxes

- Check the plots for generic waste versus PA results

5. TRANSCRIPTION:

- Ensure that the peak concentrations, peak fluxes and times in the figures match the values in the tables. If the numbers are presented at two different locations throughout the report, they should be identical, except for rounding.

Peak concentrations, fluxes and times from the figures in Appendix A were compared with Table 1 values and were correctly transcribed. Values from modeling output showing fraction remaining with time when starting with one curie of each nuclide were compared with tables 2, 3 and 4 in the report. All were correct.

- Check the inventory limit table and the tables comparing inventory with limits

Correct limits were applied. Small errors found in tables. Marked up page set in your chair.

\section{Design check from T.Hang}

\section{Design Check for Special Analysis of ETF Carbon Vessels in Slit Trenches}

\section{$\underline{\text { Item } 3}$}

- In the vadose zone, H-3_C and I-129_C were modeled in 2 stages: OKCap (i.e., intact cap from 25 years to 125 years), and BadCap (i.e., failed cap from 125 years to 10,000 years). At the start of the OKCap stage, concentration inventory was set to an initial value that was calculated from the initial inventory at time 0 and decay.

- New waste-specific $\mathrm{Kd}(7400 \mathrm{ml} / \mathrm{g})$ for I-129_C was used in the new model. In the aquifer zone, however, old Kd for generic I-129 was correctly applied.

- Overall, the modeling changes stated in the report were properly implemented. The PA models were effectively replicated excepted for the new changes.

\section{$\underline{\text { Item } 4}$}

- For each nuclide, the general pattern well concentrations were found to match the general pattern of the fluxes.

- For H-3, the plots for H-3_C are similar to those of H-3 except that the H-3_C curves are delayed (righ-shifted) by $\sim 125$ years.

- For I-129, the plots for I-129_C do not exhibit any peak due to the high new Kd. The plots for I-129 display double peaks for both concentration and flux.

- Check the plots for generic waste vs. PA results: 
$\circ$ The current special analysis and PA show identical results of peak fluxes and concentrations:

- Fractional fluxes:

1.53E-1@6.91 years (H-3)

7.27E-2@22.3 years (I-129)

- Normalized concentrations:

1.59E+3@9years $(\mathrm{H}-3)$

4.77E+2@29 years (I-129)

- In general, the plot trends for generic waste tend to agree with those shown in the PA report. An accurate comparison cannot be established since plots are displayed in different scales (i.e., larger time scale in Special Analysis; log scale for fluxes and concentrations in Special Analysis vs. linear scale for those variables in PA). 